\title{
KETERWAKILAN PEREMPUAN PADA DPRD KABUPATEN BANGKA TAHUN 2014-2019
}

\section{Rinda Oktari}

rindaoktari9@gmail.com

Program Studi IImu Administrasi Negara STISIPOL Pahlawan 12 Sungailiat, Bangka Belitung

\begin{abstract}
ABSTRAK
This research discusses about the representation of women in Bangka District in 2014-2019 to provide information about gender's inclusion in the political recruitment in the Bangka District that effect has not fulfilled its quota $30 \%$ representation of women in parliament, so that the research can provide solutions for the increased representation of women in the Bangka District. This research is a case study research done using a qualitative method. Research results suggest that the representation of women should be increased by a clear law enforcement act in the recruiting process, a social structure that involves female politicians in political parties and in parliament, mandated to pursue gender justice, and political education to cadre, future legislatif candidates and communities must be properly implemented by political and government parties so that increased representation of women can be achieved.
\end{abstract}

Penelitian ini membahas tentang keterwakilan perempuan pada DPRD Kabupaten Bangka tahun 2014-2019 guna memberikan informasi terkait pengarus-utamaan gender dalam rekrutmen politik di Kabupaten Bangka yang berdampak belum terpenuhinya kuota 30\% keterwakilan perempuan di parlemen sehingga dengan adanya penelitian ini dapat memberikan solusi dalam peningkatan keterwakilan perempuan di DPRD Kabupaten Bangka. Penelitian ini adalah penelitian studi kasus yang dilakukan dengan menggunakan metode kualitatif. Hasil penelitian menyarankan bahwa keterwakilan perempuan harus ditingkatkan karena urgensinya yang mana melalui adanya payung hukum yang jelas dalam proses rekrutmen, struktur kepengurusan yang melibatkan politisi perempuan di partai politik maupun di parlemen wajib mengedepankan keadilan gender, serta edukasi politik kepada kader, bakal calon legislatif dan masyarakat harus diimplementasikan dengan baik oleh partai politik dan pemerintah sehingga peningkatan keterwakilan perempuan dapat dicapai.

Kata Kunci: Rekrutmen Politik, Keterwakilan Perempuan, Partai Politik

\section{PENDAHULUAN}

Hasil sidang umum Perserikatan BangsaBangsa (PBB) pada 25 September 2015 di New York, Amerika Serikat, secara resmi mengesahkan Agenda Pembangunan Berkelanjutan atau SDGs (Sustainable Development Goals). SDGs berisi 17 tujuan yang salah satu tujuan dan targetnya adalah:

"Tujuan kelima SDGs adalah mencapai kesetaraan gender dan memberdayakan semua perempuan dan anak perempuan. Target kelima yaitu memastikan bahwa semua perempuan dapat berpartisipasi penuh dan mendapat kesempatan yang sama untuk kepemimpinan pada semua level pengambilan keputusan dalam kehidupan politik, ekonomi, dan publik.

Artinya, pada abad sekarang ini diharapkan tidak ada lagi bentuk diskriminasi yang dialami oleh kaum perempuan terhadap dominasi laki-laki.
Namun, berdasarkan sumber data Badan Pusat Statistik Indonesia (2018) pada 2004 hanya ada 65 perempuan $(11,82 \%)$ dari 500 anggota DPR RI, lalu pada 2009 terdapat peningkatan signifikan sebanyak $6,04 \%$, yaitu 100 perempuan $(17,86 \%)$ dari 560 anggota DPR RI, dan pada 2014 terjadi penurunan dari tahun sebelumnya sebanyak 0,54\%, yaitu terdapat 97 perempuan $(17,32 \%)$ dari 560 anggota DPR RI. Berdasarkan data Komisi Pemilihan Umum Republik Indonesia (2018), kepala dan wakil daerah perempuan yang terpilih di pilkada serentak pada 2015 berjumlah 46 orang perempuan, pilkada serentak pada 2017 berjumlah 13 orang perempuan, lalu pada pilkada serentak 2018 berjumlah 31 orang perempuan.

Kendala struktural tersebut sering kali berkaitan dengan permasalahan pendidikan, status sosial, ekonomi, dan pekerjaan. Sampai saat ini, pekerjaan perempuan masih sering diidentikkan 
dengan pekerjaan yang sulit berimbang dengan kaum laki-laki. Sementara kendala kultural terkait dengan faktor budaya yang hidup dalam masyarakat seperti menempatkan perempuan untuk sekadar tinggal di rumah. Oleh karena itu, konsep kesetaraan gender dianggap sebagai sebuah jawaban untuk mengatasi persoalan perempuan tersebut. Hal ini dapat kita lihat melalui Indeks Pembangunan Gender (IPG) yang merupakan salah satu ukuran tingkat keberhasilan capaian pembangunan yang sudah mengakomodasi persoalan gender.

Badan Pusat Statistik Indonesia (2018) menunjukkan bahwa capaian Indeks Pembangunan Gender Indonesia (IPG) Indonesia sempat mengalami penurunan pada 2016 yang disebabkan oleh pertumbuhan IPM Perempuan yang kalah cepat dibandingkan IPM Laki-laki. Pada 2017, pembangunan gender di Indonesia kembali meningkat. IPG Indonesia mengalami kenaikan 0,14 poin atau tumbuh 0,15\% dibanding pada 2016. Peningkatan IPG disebabkan oleh pertumbuhan IPM perempuan yang lebih besar dibanding IPM laki-laki pada periode 2016-2017. IPM perempuan tumbuh 0,95\%, sedikit lebih besar dibanding IPM laki-laki yang tumbuh $0,79 \%$ dibanding tahun sebelumnya. Meskipun IPG Indonesia mengalami peningkatan, capaian ini belum berhasil memulihkan tren IPG di periode 2010-2015. Nilai IPG pada 2017 masih berada sedikit di bawah capaian pada 2015 sebesar 91,03. Kemudian untuk Indeks Pembangunan Gender (IPG) Kepulauan Bangka Belitung pada 2016 sebesar 88,90\% lebih tinggi dibandingkan tahun sebelumnya, yakni $88,37 \%$, walau lebih kecil dari IPG nasional pada tahun yang sama sebesar 90,82\%. Peningkatan IPG merupakan suatu kemajuan dalam hal kesetaraan gender. Kemajuan ini disebabkan oleh komponenkomponen pembangunan perempuan terus tumbuh lebih cepat bahkan nilainya lebih tinggi dibandingkan laki-laki. $\mathrm{Hal}$ ini merupakan peningkatan yang baik untuk Kepulauan Bangka Belitung.

Berdasarkan data Badan Pusat Statistik Indonesia (2018) pada 2017, Indeks Pemberdayaan Gender (IDG) Kepulauan Bangka Belitung $(54,91)$ merupakan paling rendah kedua dari provinsi lainnya yang ada di Indonesia. Hal ini dilihat dari komponen pembentuk IDG; peningkatan IDG disebabkan oleh semakin besar kecilnya porsi sumbangan pendapatan yang diciptakan oleh perempuan, dalam hal ini Kepulauan Bangka Belitung hanya sebesar $26,17 \%$. Komponen yang lain adalah persentase perempuan dalam parlemen hanya $6,67 \%$, dan persentase perempuan sebagai tenaga profesional hanya $49,36 \%$. Kondisi ini lebih rendah dibandingkan provinsi lainnya yang ada di Indonesia.

Capaian angka-angka tersebut sebagai upaya mendorong kesetaraan peran perempuan di Indonesia, dimulai pada masa momentum Reformasi yang dialami bangsa Indonesia pada 1998 membawa perubahan pada sistem politik dan struktur ketatanegaraan Indonesia. Perubahan ini membuka peluang bagi setiap elemen bangsa terlibat di dalamnya untuk mewujudkan kehidupan demokrasi yang lebih baik. Bagi kaum perempuan di Indonesia, perubahan sistem politik dan ketatanegaraan ini juga memberi harapan bagi mereka untuk dapat memperjuangkan kepentingannya. Pasalnya, realisasi dari perubahan struktur ketatanegaraan dan sistem politik Indonesia adalah amandemen UndangUndang Dasar 1945 (selanjutnya disebut UUD 1945). Dalam proses perubahan Undang-Undang Nomor 39 Tahun 1999 tentang Hak Asasi Manusia, memuat beberapa pasal yang memberikan hak-hak kepada warga negara, yakni sebagai berikut:

1.Pasal 28C ayat (2): "Setiap orang berhak memajukan dirinya dalam memperjuangkan haknya secara kolektif untuk membangun masyarakat, bangsa, dan negaranya."

2. Pasal 28D ayat (3): "Setiap Warga Negara berhak memperoleh kesempatan yang sama dalam pemerintahan."

3. Pasal 28I ayat (2): "Setiap orang berhak bebas dari perlakuan diskriminatif atas dasar apapun dan berhak mendapatkan perlindungan terhadap perlakuan yang bersifat diskriminatif itu."

Pasal-pasal tersebut memberikan sebuah konsekuensi logis terhadap setiap orang dalam arti warga negara Indonesia, baik laki-laki ataupun perempuan, untuk memperjuangkan haknya secara kolektif tanpa ada perlakuan yang bersifat diskriminatif. Jadi, secara tidak langsung, perubahan terhadap UUD 1945 memberikan konsekuensi logis terhadap persamaan kedudukan antara perempuan dan laki-laki. Sebelum ada amandemen UUD 1945, peran perempuan dalam dunia politik sangatlah kurang. Bandingkan dengan keberadaan perempuan sebagai anggota DPR RI periode 2014-2019, yakni sebanyak 97 orang dari 560 anggota dewan.

Akibat perubahan struktur ketatanegaraan dan sistem politik Indonesia, sistem pemilihan umum (pemilu) setelah Reformasi juga mengalami perubahan. Hal ini ditandai dengan diberlakukannya 
Undang-undang Nomor 2 Tahun 1999 dan setelah itu berubah menjadi Undang-undang Nomor 2 Tahun 2008 dan berubah lagi menjadi Undangundang Nomor 2 Tahun 2011 tentang Partai Politik yang dalam beberapa pasalnya menyebutkan:

1. Pasal 2 ayat (2): "Pendirian dan pembentukan Partai Politik sebagaimana dimaksud pada ayat (1) menyertakan $30 \%$ (tiga puluh perseratus) keterwakilan perempuan."

2. Pasal 2 ayat (5): "Kepengurusan Partai Politik tingkat pusat sebagaimana dimaksud pada ayat (3) disusun dengan menyertakan paling rendah $30 \%$ (tiga puluh perseratus) keterwakilan perempuan."

3. Pasal 20: "Kepengurusan Partai Politik tingkat provinsi dan kabupaten/kota sebagaimana dimaksud dalam Pasal 19 ayat (2) dan ayat (3) disusun dengan memperhatikan keterwakilan perempuan paling rendah $30 \%$ (tiga puluh perseratus) yang diatur dalam AD dan ART Partai Politik masing-masing.”

Diberikannya angka $30 \%$ pada beberapa pasal dalam Undang-undang Partai Politik tersebut merupakan sebuah kebijakan yang dilakukan oleh pembentuk undang-undang, yaitu pemerintah dan DPR, dalam upaya memberdayakan kaum perempuan di Indonesia agar mempunyai kesempatan yang sama berpartisipasi dalam dunia politik, khususnya masuk dalam struktur kepengurusan partai politik.

Kebijakan tersebut merupakan sebuah kebijakan affirmative action atau pemberian perlakuan khusus di Indonesia. Pemberian perlakuan khusus yang diberikan kepada kaum perempuan merupakan upaya meningkatkan keikutsertaan perempuan dalam dunia politik seperti keterwakilan perempuan dalam DPR-RI, DPD, dan DPRD serta lembaga lainnya. Dengan adanya kebijakan tersebut, diharapkan keterwakilan perempuan dalam kepengurusan partai politik sesuai Penjelasan atas Undang-undang Nomor 2 Tahun 2011 tentang Partai Politik yang berisi:

"Memaksimalkan fungsi partai politik terhadap negara maupun fungsi partai politik terhadap rakyat melalui pendidikan politik dan pengkaderan serta rekrutmen politik yang efektif untuk menghasilkan kader-kader calon pemimpin yang memiliki kemampuan di bidang politik.”

Dengan demikian, keterwakilan perempuan tersebut bukan hanya sebagai pelengkap dalam politik. Akan tetapi, perempuan harus dilibatkan dalam memberikan pemahaman, pendidikan, dan pengambil keputusan serta pengetahuan bagi masyarakat luas. Bagaimanapun juga permasalahan perempuan sangat banyak dan butuh fokus penanganan sehingga harus ada peningkatan angka keterwakilan perempuan di parlemen supaya bisa memperjuangkan isu-isu perempuan, memberdayakan perempuan, memenuhi keseimbangan hak-hak perempuan, serta meningkatkan kualitas kehidupan perempuan.

Pemenuhan angka 30\% dalam keterwakilan perempuan yang harusnya menjadi penggerak kepentingan perempuan ternyata berbanding terbalik dengan pemenuhan kuota perempuan yang duduk di DPRD Kabupaten Bangka. Hal ini berdasarkan Badan Pusat Statistik (2018), yakni pada 2004-2009 hanya ada 2 perempuan $(6,6 \%)$ dari 30 anggota DPRD, sementara pada 2009-2014 hanya ada 4 perempuan $(13,3 \%)$ dari 30 anggota DPRD, dan pada 2014-2019 dari sebanyak 35 kursi hanya 7 $(20 \%)$ kursi yang diisi oleh kaum perempuan, yaitu 2 orang Partai Golkar, 2 orang Partai Gerindra, 1 orang Partai Nasdem, 1 orang partai PDI-P, dan 1 orang partai PAN. Dengan demikian, keterwakilan perempuan di DPRD Kabupaten Bangka belum mencapai target 30\%. Padahal, perempuan harus memiliki kesempatan yang sama dalam berinteraksi di dalam ruang publik, sesuai dengan hak asasi perempuan yang dijamin secara konstitusional dalam Pasal 28D ayat (3) UUD Negara Republik Indonesia Tahun 1945 bahwa setiap warga negara berhak memperoleh kesempatan yang sama dalam pemerintahan.

Di sisi yang lain, proporsi jumlah penduduk perempuan dan laki-laki di Kabupaten Bangka hampir berimbang. Data Dinas Kependudukan dan Pencatatan Sipil Kabupaten Bangka mencatat bahwa dari $48,38 \%$ total populasi adalah perempuan, sedangkan 51,62\% adalah laki-laki. Dengan kondisi ini tentunya keterwakilan perempuan di parlemen harus ditingkatkan lagi. Bagaimanapun juga untuk menjamin proses perumusan dan pengambilan kebijakan terkait isu-isu perempuan, fokus penanganannya akan lebih tepat bila dilakukan oleh perempuan sehingga memang benar-benar berdampak langsung bagi perempuan.

Menurut Erwan dan Dyah (2015: 125), keberhasilan implementasi suatu kebijakan sangat dipengaruhi oleh mekanisme penyampaian (delivery mechanism), yaitu bagaimana keluaran-keluaran kebijakan (policy output) dapat sampai kepada 
kelompok sasaran dengan berbagai kriteria seperti tepat sasaran, waktu, dan lain-lain, untuk menjamin munculnya hasil kebijakan, baik hasil kebijakan yang langsung dirasakan maupun yang akan muncul dalam jangka panjang. Oleh karena itu, dalam konteks ini menjadi penting proses rekrutmen politik partai, yang merupakan ajang untuk mencari dan menyeleksi keanggotaan baru untuk diikutsertakan dalam partai politik. Rekrutmen politik sebagai pembelajaran politik dan regenerasi dalam partai politik, dilakukan melalui mekanisme yang diterapkan oleh partai. Pengaruh rekrutmen politik sangat menentukan dalam regenerasi kehidupan partai. Hal itu dikarenakan partai memerlukan penyegaran keanggotaan untuk dapat bertahan dalam mempertahankan kekuasaan politiknya di masyarakat. Tentu saja dalam proses rekrutmen masing-masing partai politik memiliki tata cara yang berbeda-beda sehingga tiap partai politik tentu memiliki keunggulan masing-masing dan juga permasalahan yang beragam. Penelitian ini akan melihat adanya perbedaan dan keberagaman tata cara juga kriteria partai politik dalam menentukan dan merekrut anggotanya untuk menjadi wakil rakyat yang menduduki kursi sebagai anggota DPRD.

Penelitian sebelumnya sudah pernah dikaji dengan judul "Rekrutmen Politik terhadap Perempuan dalam Partai Politik dan Parlemen 20042009” oleh Fanina Fanindita dengan fokus kajian pada permasalahan keterwakilan perempuan berkaitan dengan kebijakan partai politik. Pada penelitian ini kajian difokuskan pada proses pola rekrutmen politik dan faktor yang mempengaruhi keterwakilan perempuan untuk meningkatkan keterwakilan perempuan di parlemen.

\section{LANDASAN TEORI}

\section{Pengertian Gender dan Pemberdayaan Perempuan}

Ann Oakley dalam Nugroho (2008: 3) mengartikan gender sebagai konstruksi sosial atau atribut yang dikenakan pada manusia yang dibangun oleh kebudayaan manusia. Gender merupakan perbedaan perilaku (behavioral differences) antara laki-laki dan perempuan yang dikonstruksi secara sosial, yaitu perbedaan yang bukan ketentuan Tuhan melainkan diciptakan oleh manusia melalui proses sosial dan kultural yang panjang.

Mengacu pada pendapat Saparinah Sadli dalam Rasyidin dan Aruni (2016: 24), proses pemberdayaan kaum perempuan dengan tujuan pengembangan kesetaraan gender dilakukan melalui kegiatan seperti berikut:

1. Mempromosikan partisipasi perempuan sebagai agen pembaharuan dalam proses politik, ekonomi, maupun sosial. Untuk itu, dimestikan partisipasi dalam bentuk jumlahnya maupun meningkatkan haknya dalam upaya peningkatan partisipasi perempuan.

2. Kolaboratif antara laki-laki dan perempuan karena pemberdayaan perempuan untuk mencapai kesetaraan gender ini berarti perubahan sikap atau perubahan perilaku. Perubahan peran antara laki-laki dan perempuan yang menjadi hak dan kewajibannya yang seimbang di antara mereka, baik dalam keluarga, pekerjaan, maupun dalam masyarakat.

3. Upaya-upaya khusus yang dapat menghilangkan ketimpangan gender di berbagai tingkatan dan juga mencabut hukum yang diskriminatif dan tidak ramah gender.

\section{Keterwakilan Perempuan melalui Kebijakan Afirmasi}

Menurut Ani Widyani Soetjipto (2005: 28), perempuan sebagai kategori politik pada dasarnya dapat berpartisipasi dalam bentuk tidak langsung, yaitu sebagai wakil kelompok perempuan yang bisa merepresentasikan kepentingan kelompok mereka. Menurut United Nations Development Program (UNDP) dalam Rasyidin dan Aruni (2016: 46), terbatasnya keterwakilan perempuan di pemerintah kabupaten dapat berujung pada tidak terpenuhinya kebutuhan, tidak teratasinya kekhawatiran perempuan, dan prioritas-prioritas pembangunan dalam rencana pembangunan daerah dan mungkin akan mempertegas pemarginalan perempuan dalam mendapatkan pelayanan sosial di tingkatan lokal. Keterwakilan perempuan dalam artian ini adalah untuk menyuarakan kepentingan perempuan. Pada titik ini, yang banyak diabaikan oleh banyak kalangan, bahkan termasuk oleh kalangan perempuan sendiri, adalah bahwa kepentingan perempuan memang lebih baik disuarakan oleh perempuan sendiri karena mereka yang sesungguhnya paling mengerti kebutuhankebutuhan perempuan.

\section{Rekrutmen Politik}

Rekrutmen Politik merupakan tahapan dari suatu proses yang melibatkan individu dari politik pasif ke politik aktif. Rekrutmen politik dalam penelitian ini digunakan 
untuk menunjukkan rekrutmen kader sebagai tahap awal bagian pengikutsertaan perempuan di parlemen. Menurut Czudnowski dalam Fadillah Putra (2007: 103), model yang digunakan partai politik dalam rekrutmen politik antara lain:

\section{Rekrutmen terbuka}

Syarat dan prosedur untuk menampilkan seseorang tokoh dapat diketahui secara luas. Dalam hal ini partai politik berfungsi sebagai alat bagi elite politik yang berkualitas untuk mendapatkan dukungan masyarakat. Cara ini memberikan kesempatan bagi rakyat untuk melihat dan menilai kemampuan elite politiknya. Dengan demikian, cara ini sangat kompetitif. Jika dihubungkan dengan paham demokrasi, maka cara ini juga berfungsi sebagai sarana rakyat mengontrol legitimasi politik para elite. Dengan menerapkan pola rekrutmen terbuka, alur pendaftaran calon menggunakan stelsel aktif, yakni dengan keaktifan calon sendiri untuk memenuhi berbagai persyaratan yang ditetapkan tim panitia pendaftaran yang kemudian dilanjutkan dengan proses seleksi.

\section{Rekrutmen tertutup}

Berlawanan dengan cara rekrutmen terbuka, dalam rekrutmen tertutup ini syarat dan prosedur pencalonan tidak dapat secara bebas diketahui umum. Partai berkedudukan sebagai promotor elite yang berasal dari dalam tubuh partai itu sendiri. Cara ini menutup kemungkinan bagi anggota masyarakat untuk melihat dan menilai kemampuan elite yang ditampilkan. Dengan demikian, cara ini kurang kompetitif. Hal ini menyebabkan demokrasi berfungsi sebagai sarana elite memperbaharui legitimasinya. Pola rekrutmen tertutup berlaku bagi perekrutan calon legislatif yang berasal dari kader partai sendiri. Untuk pengumuman pencalonan bagi kader partai (internal) tentu lebih mudah, semisal dengan memanfaatkan agenda rapat partai. Dalam rapat tersebut dapat diumumkan bagi kader partai yang hendak mendaftar ataupun mencalonkan diri sebagai calon legislatif partai. Pola rekrutmen tertutup ini menggunakan stelsel pasif, yakni calon legislatif dihubungi dan ditunjuk oleh partai untuk maju sebagai calon legislatif dengan dibantu untuk memenuhi sebagian persyaratan yang telah ditetapkan, misalkan pengurusan administrasi kesehatan, pengurusan dokumen-dokumen tertentu, dan lain-lain.

Menurut Lily Romli (2005: 93), ada beberapa pola kecenderungan partai politik dalam melakukan rekrutmen politik terhadap calonnya, yakni sebagai berikut:
1. Partisipan. Pendukung yang kuat, loyalitas tinggi terhadap partai sehingga bisa direkrut untuk menduduki jabatan strategis, biasanya kader internal partai.

2. Compartmentalization. Proses rekrutmen yang didasarkan pada latar belakang pendidikan dan pengalaman organisasi atau kegiatan sosial politik seseorang.

3. Immediate Survival. Proses rekrutmen dilakukan oleh otoritas pemimpin partai tanpa memperhatikan kemampuan orang-orang yang direkrut.

4. Civil Service Reform. Proses rekrutmen berdasarkan kemampuan dan loyalitas seorang calon sehingga bisa mendapatkan kedudukan lebih tinggi atau penting; contohnya non-kader partai yang mempunyai kedekatan dengan partai tersebut dalam tahapan penetapan calon legislatif.

Menurut Nimmo (2000: 47) dalam Zaenal Mukarom (Mediator, Volume 9, Nomor 2, Desember 2008), keterlibatan seseorang dalam partisipasi politik dipengaruhi oleh faktor-faktor sebagai berikut:

1. Peluang resmi, artinya ada kesempatan seseorang terlibat dalam partisipasi politik karena didukung kebijakan-kebijakan yang dibuat oleh negara.

2. Sumber daya sosial, artinya partisipasi ditentukan oleh kelas sosial dan perbedaan geografis. Dalam kenyataannya, tidak semua orang memiliki peluang yang sama berkenaan dengan sumber daya sosial dan sumber daya ekonomi untuk terlibat dalam partisipasi politik. Berkaitan dengan perbedaan geografis, terdapat juga perbedaan dalam partisipasi seperti usia, jenis kelamin, suku, tempat tinggal, agama, dan lainlain.

3. Motivasi diri, artinya motif yang mendasari kegiatan berpolitik sangat bervariasi. Motif ini bisa disengaja ataupun tidak disengaja, rasional ataupun tidak rasional, diilhami psikologis atau sosial, diarahkan dari dalam diri sendiri atau dari luar, dan dipikirkan atau tidak dipikirkan.

\section{METODE PENELITIAN}

Menurut Strauss dan Corbin (2009: 4), penelitian kualitatif adalah jenis penelitian yang temuan-temuannya tidak diperoleh melalui prosedur statistik atau bentuk hitungan lainnya. Menurut Surachrnad dalam Prastowo (2011: 128), studi kasus dijelaskan sebagai jenis penelitian yang berfokus dan memperhatikan dengan saksama suatu kasus dengan intensif dan rinci, dengan penggalian informasi dan analisis secara mendalam. 
Jenis penelitian yang dipergunakan peneliti adalah studi kasus yang dilakukan dengan menggunakan metode kualitatif. Teknik pengumpulan data yang digunakan dalam penelitian ini berupa studi kepustakaan dan studi lapangan yang meliputi observasi dan wawancara. Proses analisis datanya meliputi reduksi data, penyajian data, dan penarikan kesimpulan/verifikasi.

\section{PEMBAHASAN PENELITIAN}

\section{Mekanisme Rekrutmen dan Pendaftaran Bakal Calon Legislatif}

Rekrutmen politik merupakan tahapan dari suatu proses yang melibatkan individu dari politik pasif ke politik aktif. Rekrutmen politik dalam penelitian ini digunakan untuk menunjukkan rekrutmen kader sebagai tahap awal bagian pengikutsertaan perempuan di parlemen. Pada pembahasan yang akan dijabarkan, peneliti menggunakan teori Czudnowski dalam Fadillah Putra (2007: 103), yang mengemukakan model yang digunakan partai politik dalam rekrutmen politik, yakni:

\section{Rekrutmen Terbuka}

Mekanisme rekrutmen dan pendaftaran bakal calon legislatif yang dilakukan pada 10 partai politik yang mempunyai kursi di parlemen pada 2014-2019 dalam prosesnya terdapat persamaan dan juga perbedaan. Terdapat 8 partai politik yang terdiri dari PKS, Gerindra, Demokrat, Nasdem, PPP, PKPI, Hanura, dan PAN yang mempunyai model rekrutmen terbuka, alur pendaftaran calon menggunakan stelsel aktif, yakni dengan keaktifan calon sendiri untuk memenuhi berbagai persyaratan yang ditetapkan tim panitia pendaftaran yang kemudian dilanjutkan dengan proses seleksi. Oleh karena itu, 8 (delapan) partai politik membuka seluas-luasnya kepada seluruh masyarakat yang ingin ikut serta mencalonkan diri melalui partai politik ketika pendaftaran sudah dibuka dan akan diseleksi untuk tahapan selanjutnya.

Berdasarkan temuan, rekrutmen terbuka sebagai ciri keterbukaan partai politik disertai pula dengan pola immediate survival, yakni proses rekrutmen dilakukan oleh otoritas pemimpin partai tanpa memperhatikan kemampuan orang-orang yang direkrut. Proses semacam ini seyogianya tetap perlu dilakukan dengan baik dan terarah sebagai bentuk komitmen partai politik dalam berdemokrasi. Jangan sampai sosok yang dicalonkan bukanlah seseorang yang berkompetensi dalam ranah politik untuk duduk di parlemen, terlebih lagi partai politik tidak melakukan pembekalan selama proses pencalonan.

Berdasarkan temuan dari wawancara dengan 8 partai, syarat yang diberikan untuk perekrutan calon anggota legislatif hanyalah bersifat umum dan administratif. Ini bisa dilihat dari persyaratan standar, yakni mempunyai KTA (Kartu tanda anggota) partai tersebut, siap loyal terhadap partai, dan tingkat pendidikan minimal SMA atau yang sederajat. Sayangnya, persyaratan itu tidak diimbangi dengan adanya seleksi khusus dengan para calon. Bisa jadi ada kendala dalam hal waktu. Memang tempo rekrutmen partai politik dilakukan setelah KPU mengumumkan waktu pendaftaran atau sekitar 8 bulan sebelum pemilu. Hanya dua partai, yakni PAN dan Nasdem, yang membuka pendaftaran 1-2 tahun sebelum pemilu. Partai-partai lainnya, seperti PKS, Gerindra, Demokrat, PPP, PKPI, dan Hanura, melakukan penjaringan terbuka bagi kader dan non-kader setelah ada pengumuman dari KPU.

Hasil wawancara dengan Drs. APRI, sekretaris PPP, pada 20 Januari 2020 me menyebutkan:

"Dilakukan pengumuman 6-7 bulan sebelum pemilu dari partai dan dibuka untuk kader dan nonkader, maka mengikuti proses seleksi oleh lajnah penetapan calon.”

Penilaian seleksi pun hanya dilakukan dengan sistem wawancara, survei elektabilitas, penilaian indikator seperti ijazah dan pengalaman organisasi, dan hanya diberikan pengarahan (alihalih pendidikan politik yang seharusnya). Hanya PAN dan Nasdem yang melakukan pembekalan kepada calon dalam rentang waktu yang lama sehingga calon benar-benar siap menjadi legislatif. Dengan temuan ini, bagi partai-partai yang memang membuka secara umum pendaftarannya, diperlukan keseriusan mengusung kader yang memang mumpuni dan berkualitas; bukan hanya memasang kader untuk melengkapi kuota pemilihan per daerah pemilihan (dapil). Ringkasnya, ke depan partaipartai semestinya perlu menerapkan seleksi yang lebih serius lagi saat pencalonan. Hal ini sejalan dengan Undang-undang Nomor 2 Tahun 2011 tentang Partai Politik. Partai politik harus memaksimalkan fungsinya terhadap negara maupun terhadap rakyat melalui pendidikan politik dan pengkaderan serta rekrutmen politik yang efektif untuk menghasilkan kader-kader calon pemimpin yang memiliki kemampuan di bidang politik. 
Proses pencalonan penting untuk diperhatikan mengingat hasilnya akan berpengaruh pada kualitas calon yang ditempatkan di parlemen. Dalam beberapa kasus, ada temuan bahwa walaupun sudah lulus seleksi tapi calon tersebut sebenarnya belum terlalu maksimal menurut perhitungan objektif. Akan tetapi, partai "memaksakan" calon tersebut untuk terus maju dicalonkan. Keadaan semacam ini riil adanya; bagaimanapun juga publik bisa mengkritisi pemahaman dan kualitas dari seorang calon wakil rakyat yang diseleksi hanya 6-7 bulan sebelum pemilu. Oleh karena itu, sudah seharusnya partai-partai memberikan perhatian dan pendidikan politik rutin secara khusus, dan hal-hal yang berkaitan tentang permasalahan bangsa, kepada para kadernya $\mathrm{Hal}$ ini bertujuan agar peran yang akan mereka jalankan saat terpilih di parlemen benar-benar dipahami dan dijalankan dengan baik. Oleh karena itu, pendidikan politik dan kaderisasi haruslah merupakan proses yang terus-menerus, yang dirancang dan diarahkan secara tertib, teratur dan berjenjang; bukan dilakukan hanya 8 bulan sebelum pemilu. Dengan demikian, calon yang diajukan bukan hanya sebagai pelengkap kuota saja dikarenakan kader yang dicalonkan memang sudah paham dan mumpuni terkait fungsi dan peran sebagai anggota legislatif.

Terkait penempatan perempuan yang dilakukan berselang-seling, yakni di antara setiap nomor urut 1-3, 4-6 dan 7-10 harus diisi oleh perempuan, hal ini disebabkan adanya peraturan dari KPU dan berdasarkan musyawarah. Sayangnya, mekanisme penempatan seperti ini di lapangan justru terkesan seolah-olah perempuan tidak ditekankan untuk benar-benar duduk di parlemen. Pasalnya, belum ada perempuan yang ditempatkan pada nomor urut 1 di dapil yang ada. Padahal, dalam Undang-undang Nomor 7 Tahun 2017 tentang Pemilihan Umum ditandaskan:

"Bahwa daftar bakal calon memuat keterwakilan perempuan paling sedikit $30 \%$, dan apabila tidak memuat keterwakilan perempuan paling sedikit 30\%, maka KPU memberikan kesempatan partai politik untuk memperbaiki daftar bakal calon tersebut.”

Tidak hanya itu, berdasarkan Peraturan KPU Nomor 20 Tahun 2018 tentang Pencalonan Anggota DPR, DPRD Provinsi, dan DPRD Kabupaten Kota: "Daftar bakal calon yang wajib memuat keterwakilan perempuan paling sedikit 30\% di setiap dapil dan di setiap 3 orang bakal calon pada susunan daftar calon wajib terdapat paling sedikit 1 orang calon perempuan."
Dapat disimpulkan bahwa keterwakilan perempuan sudah ditekankan dalam regulasi tapi dalam penerapannya belum berjalan baik. Perempuan ditempatkan pada urutan nomor yang tidak strategis. Wawancara dengan pengurus Partai Demokrat, Ibu Dana Purnamasari, pada 15 Januari 2020, menyebutkan:

"Dilakukan secara selang-seling karena ketentuan dari KPU, tapi biasa nomor urut 1 dari ketua."

Begitu pula wawancara dengan ketua partai PKPI, Bapak Ramadian, pada 22 Januari 2020:

"Ketua diprioritaskan nomor satu dan kader yang lain melalui musyawarah dengan calon dan kepengurusan, perempuan ditempatkan dengan selang-seling.”

Wawancara dengan wakil sekretaris Partai Hanura, Bapak Herry, pada 22 Januari 2020:

"Dilakukan selang-seling antara perempuan dan laki-lakinya sesuai ketentuan KPU, dan itu ditentukan oleh ketua partai nomor urut 1."

Walaupun begitu, tetap ada partai yang menggunakan sistem skor dan survei elektabilitas, serta musyawarah dalam menempatkan perempuan dan laki-laki di nomor urut yang memang seharusnya sesuai kemampuan. Jadi, penempatan calon bukan berdasarkan kepengurusan partai. $\mathrm{Hal}$ ini berlaku di PAN dan Nasdem yang menempatkan bakal calon legislatif berdasarkan hasil seleksi sistem skor dan survei elektabilitas dengan tujuan agar terjadi keadilan dalam penentuan nomor urut. Dengan begitu, kesempatan perempuan benar-benar sama dengan laki-laki dalam penempatan; bukan hanya pelengkap tapi memang diunggulkan sesuai kemampuan dan potensi. Dalam sistem demokrasi yang masyarakatnya belum benar-benar paham mengapa keterwakilan perempuan itu penting, diperlukan dukungan dan posisi yang strategis bagi perempuan untuk beradu di ranah publik yang patriarkis sebagai dukungan lebih dan kesungguhan partai menerapkan 30\% keterwakilan perempuan. Di delapan partai yang diteliti, rata-rata keterwakilan perempuannya memang sebesar $36,4 \%$ (di atas angka minimal), namun jangan sampai besaran ini sekadar angka tapi seharusnya memiliki makna yang pasti sebab upaya yang diberikan kepada perempuan memang sudah maksimal.

\section{Rekrutmen Tertutup}

Mekanisme rekrutmen dan pendaftaran bakal calon legislatif secara tertutup dilakukan oleh dua 
partai politik, yakni PDI-P dan Golkar. Keduanya menganut model rekrutmen tertutup, yakni perekrutan calon legislatif berasal dari kader partai sendiri. Pola rekrutmen tertutup ini menggunakan stelsel pasif, yakni calon legislatif dihubungi dan ditunjuk oleh partai untuk maju sebagai calon legislatif dengan dibantu untuk memenuhi sebagian persyaratan yang ditetapkan.

Wawancara dengan Ibu Arniawati, S.Sos., wakil ketua Bidang Buruh, Tani, Nelayan, Perempuan dan Anak PDI-P, pada 7 Januari 2020:

"Perekrutan dilakukan dimulai dari struktur kepengurusan DPC yang lebih diutamakan, PAC, ranting dan bila kurang maka diambil dari kader PDI-P yang ingin ikut. Tidak membuka yang bukan non-kader. Biasa hanya untuk kader; dibuka jika kekurangan.”

Untuk Partai Golkar, data didasarkan atas wawancara dengan Bapak Ujang Supryanto selaku wakil ketua I Golkar pada 9 Januari 2020:

"Di Golkar ada sistem PDPLT (prestasi, dedikasi, loyalitas dan tidak tercela). Golkar merekrut kader-kader bangsa itu melihat dari PDPLT, apakah dia punya prestasi di masyarakat atau profesinya, dan apakah punya dedikasi, punya loyalitas yang ditekan saat perekrutan kader, dan calon kader tersebut tidak tercela. Semua kalangan boleh ikut juga bahkan anak muda punya wadah AMG (Angkatan Muda Partai Golkar), dari binaan mahasiswa Kosgoro, dan lain-lain. Golkar menyiapkan kadernya dari bawah dan tidak main comot lima tahun sekali, tapi sudah terseleksi melalui kader binaan seperti AMPI, organisasi mahasiswa kekaryaan dan nanti akan ditarik menjadi kader kepengurusan partai utama.”

Dapat disimpulkan sistem yang digunakan oleh kedua partai ini tertutup untuk non-kader. Pada saat pendaftaran bakal calon legislatif, keduanya menggunakan pola partisipan yang mana pendukung yang kuat, loyalitas tinggi, kemampuan dan potensi yang telah diberikan terhadap partai bisa direkrut untuk menduduki jabatan strategis. Dalam hal ini biasanya partisipan tersebut diisi oleh kader internal partai. Bersamaan itu, berlaku pula pola compartmentalization, yakni proses rekrutmen yang didasarkan pada latar belakang pendidikan dan pengalaman organisasi atau kegiatan sosial politik seseorang. Dalam penentuan bakal calon legislatif, yang diutamakan oleh kedua partai itu adalah kader dari internal yang memiliki loyalitas terhadap partai dan punya latar belakang sesuai dengan keinginan partai. Rekrutmen dan pencalonan seperti ini memang baik dilakukan. Dengan demikian, kader yang dicalonkan memang mempunyai kualitas yang baik dan mumpuni. Akan tetapi, saat yang sama, hal tersebut menutup kesempatan masyarakat umum untuk terlibat atau berandil melalui kedua partai itu jika ingin menyuarakan hak politiknya saat proses pendaftaran pemilu berlangsung.

Terkait jenjang kaderisasi, dari hasil wawancara diperoleh informasi bahwa PDI-P tidak terlalu mempertimbangkan jenjang kaderisasi selagi calon tersebut kader. Adapun Golkar, partai ini sangat mengedepankan kader potensial yang dimiliki melalui sayap-sayap partainya. Hal ini tentunya bisa mempengaruhi dalam proses pemilihan nanti yang membuat peluang politik di parlemen dikuasai oleh elite yang berkepentingan saja.

Terkait peran politik perempuan, kedua partai mempunyai persentase keterwakilan perempuan sebesar $36,4 \%$ yang dihitung berdasarkan rata-rata keterwakilan perempuan di tiap dapil yang ada. Jika dilihat dari angka, maka jumlah keterwakilan perempuan ini sudah memenuhi kuota yang ditentukan, yakni melebihi batas $30 \%$ keterwakilan. Namun, prioritas perempuan belum terlalu dikedepankan oleh kedua partai, seakan-akan perempuan sekadar pelengkap. Buktinya adalah belum ada nomor urut 1 di setiap dapil yang diisi oleh perempuan. Padahal, berdasarkan Peraturan KPU Nomor 20 Tahun 2018 tentang Pencalonan Anggota DPR, DPRD Provinsi, dan DPRD Kabupaten Kota:

"Daftar bakal calon yang wajib memuat keterwakilan perempuan paling sedikit 30\% di setiap dapil dan di setiap 3 orang bakal calon pada susunan daftar calon wajib terdapat paling sedikit 1 orang calon perempuan."

Berdasarkan wawancara dengan Ibu Arniawati, S.Sos., wakil ketua Bidang Buruh, Tani, Nelayan, Perempuan dan Anak PDI-P, pada 7 Januari 2020 disebutkan:

"Dilakukan selang-seling sesuai ketentuan KPU, yang penting perempuan $30 \%$ keterwakilan."

Sementara itu, untuk Partai Golkar, berdasarkan wawancara dengan Bapak Ujang Supryanto selaku wakil ketua I Golkar, pada 9 Januari 2020 bersikap:

"Dilakukan secara musyawarah tapi yang dari kepengurusan diutamakan dan untuk perempuan diselang-seling dengan laki-laki sesuai ketentuan KPU.” 
Berdasarkan temuan informasi tersebut, dapat dilihat bahwa peran perempuan dalam partai tidak terlalu diperhitungkan, hanya semata-mata karena perintah undang-undang yang menghendaki kuota minimal 30\% untuk caleg perempuan, betapapun calon-calon yang diajukan adalah kader-kader potensial. Kondisi seperti ini sudah tentu akan menjadi tantangan bagi perempuan.

Sistem rekrutmen yang dilakukan partai politik di Kabupaten Bangka semestinya mampu memberikan dampak bagi peran perempuan. Sayangnya, wakil perempuan di legislatif, pada saat yang sama, belum sepenuhnya optimal berkiprah. Berdasarkan hasil wawancara dengan Ibu Surya Erni selaku anggota DPRD periode 2014-2019 dari Nasdem pada 13 Januari 2020:

"Peran perempuan belum maksimal karena belum ada ketua DPRD perempuan, dan untuk kuantitas hanya seadanya, belum terlalu maksimal walau ada sedikit, dan untuk kualitas sebenarnya perempuan sama saja intelektualnya, malah perempuan punya ketelitian yang lebih dibanding laki-laki."

Wawancara dengan Ibu Deasy Arisandi, anggota DPRD periode 2014-2019 dari Partai Gerindra pada 13 Januari 2020:

"Untuk partai sudah maksimal dengan menempatkan perempuan di kepengurusan partai, memenuhi kuota yang ditetapkan, namun untuk di DPRD belum maksimal karena perempuan yang ada memang baru bisa berjalan sesuai tupoksinya dan dengan jumlah yang belum seimbang antara perempuan dan laki-laki membuat suara perempuan belum terlalu besar di DPRD, walaupun sudah diberikan ruang dan dukungan yang tetap ada, bahkan suara perempuan sangat didengar tapi tetap saja kekuatannya belum seimbang."

Wawancara dengan Ibu Acit Karvina, anggota DPRD periode 2014-2019 dari PDI-P, pada 22 Januari 2020:

"Peran perempuan di partai untuk menyertakan $30 \%$ sudah, tapi untuk di DPRD belum karena belum sampai 30\% keterwakilannya terpenuhi. Dan itu memberikan sedikit ruang bagi perempuan untuk lebih jauh menyuarakan kepentingan perempuan walaupun tetap ada dukungan dari laki-laki.”

Wawancara dengan Ibu Suharrina, anggota DPRD periode 2014-2019 dari PAN, pada 23 Januari 2020:

"Belum terlalu maksimal karena di PAN belum pernah ada ketua partai perempuan, lalu perempuan masih perlu belajar terus untuk memberikan sumbangsih terbaik untuk partai, perlu kader perempuan yang mandiri baik secara finansial dan lain-lain, serta harus punya semangat tinggi untuk berperan di semua kalangan masyarakat. Dan untuk di DPRD bisa terlihat dari jumlah kursi keterwakilan perempuannya belum $30 \%$, padahal harusnya setidaknya minimal 11 kursi terisi oleh perempuan. Sejauh ini perempuan di DPRD bergerak sesuai tupoksinya, belum ada terlihat yang benar-benar membawa isu perempuan karena sedikitnya jumlah perempuan. Dan saya sendiri pun hanya 1 tahun menjabat tahun lalu, itu pun PAW, jadi belum maksimal dan masih butuh waktu lagi untuk berbuat lebih banyak."

Berdasarkan hasil wawancara di atas terlihat bahwa para anggota dewan yang perempuan belum optimal menyuarakan isu terkait perempuan. Para legislator perempuan hanya menjalakan tupoksi yang telah ditetapkan dan tidak mendapatkan posisi yang strategis dalam jabatan pengambilan keputusan. Hasilnya, tentu saja ini semakin menutup peluang bagi politisi perempuan untuk berkiprah lebih maksimal dalam dunia politik. Dengan demikian, sehebat apa pun kiprah politisi perempuan dalam mewarnai dinamika proses kebijakan publik, pada akhirnya masih termarginalkan. Adapun untuk menyuarakan isu perempuan, keberadaan mereka juga belum maksimal, terutama akibat segi kuantitas, yakni sedikitnya kekuatan perempuan di parlemen. Dari 7 anggota perempuan di DPRD Kabupaten Bangka, sebanyak 2 anggota merupakan PAW selama satu tahun. Terjadinya ketidakseimbangan ini membuat keterwakilan perempuan di parlemen semacam pelengkap saja karena berfungsi sama dengan pihak laki-laki yang menjalankan fungsi sesuai tupoksi. Tidak heran bila untuk merepresentasikan kepentingan perempuan dalam pembuatan suatu kebijakan, maka akan didapati kendala dan kesulitan. Ambil contoh dalam penanganan terkait permasalahan ketimpangan gender yang ada dalam segala sektor, dalam konteks ini para pembuat kebijakan yang ada belum terlalu responsif gender menempatkan perempuan pada posisi yang strategis. Lagi-lagi hal ini disebabkan oleh salah satunya adalah keterbatasan jumlah keterwakilan perempuan. Keterbatasan keterwakilan perempuan jelas berpengaruh pada keluaran-keluaran kebijakan yang seharusnya mengatasi permasalahan yang ada terkait perempuan.

$$
* * *
$$


Berdasarkan hasil analisis di atas, dapat disimpulkan bahwa partai politik di Kabupaten Bangka menggunakan model rekrutmen campuran, yaitu terbuka dengan sistem stelsel aktif yang mempunyai pola immediate survival dan model tertutup dengan sistem pasif yang mempunyai pola partisipan dan compartmentalization. Masing-masing model rekrutmen ini memiliki kekurangan dan kelebihan sehingga hal ini harus dipertimbangkan oleh partai dalam menjalankan komitmen untuk mengikutsertakan perempuan di dunia politik. Bagaimanapun juga rekrutmen yang dilakukan akan mempengaruhi kuantitas, kualitas, dan keterwakilan perempuan di parlemen.

Menurut Shvedova dalam Ranto (2019: 14), keterbatasan politisi perempuan dalam mengaktualisasikan aspirasi politiknya disebabkan oleh struktur politik dalam proses rekrutmen perempuan di arena politik. Ketika proses rekrutmen perempuan tidak dijalankan dengan maksimal, tingkat representasi perempuan lebih berfungsi sebagai untuk mempertahankan status quo daripada berfungsi bagi demokratisasi sebagaimana yang diinginkan. Ketika proses rekrutmen yang dilakukan tidak disertai prosedur-prosedur yang tertulis dan mengikat, kualitas perempuan yang dicalonkan pun seakan-akan tidak sungguh-sungguh diunggulkan. Hal ini bisa dilihat dari tidak ditempatkannya perempuan pada posisi urutan strategis sehingga akhirnya politisi perempuan sulit mendapatkan tempat di ranah publik patriarkis yang masyarakatnya cenderung masih awam terkait keterwakilan perempuan di parlemen.

Oleh karena itu, perlu pendidikan politik yang baik dilakukan kepada kader dan bakal calon legislatif. Selain itu, perlu ada sosialisasi kepada masyarakat, terkhusus perempuan, untuk mau menyuarakan bahwa keterwakilan perempuan di parlemen itu sangat penting dan perempuan sudah waktunya diberikan ruang yang sama dengan lakilaki. Dengan begitu keterwakilan perempuan dapat ditingkatkan dari segi kuantitas dan kualitas, dan ujungnya adalah permasalahan-permasalahan terkait perempuan dapat ditangani dengan maksimal oleh legislator perempuan yang memang diharapkan berperan vokal di parlemen untuk kepentingan perempuan. Secara jumlah, kaum perempuan dan laki-laki di Kabupaten Bangka hampir seimbang. Jika saja partai politik berperan dengan baik dalam proses rekrutmen, kaderisasi, dan edukasi masyarakat, maka langkah ini sebenarnya akan membuat keterwakilan perempuan lebih mudah dicapai.

\section{Faktor yang Mempengaruhi Keterwakilan Perempuan}

Pada pembahasan yang akan dijabarkan, peneliti menggunakan teori menurut Nimmo (2000: 47) dalam Zaenal Mukarom (Mediator, volume 9, Nomor 2, Desember 2008). Nimmo menjelaskan bahwa keterlibatan seseorang dalam partisipasi politik dipengaruhi oleh faktor-faktor sebagai berikut:

\section{Peluang resmi}

Kesempatan seseorang terlibat dalam partisipasi politik karena didukung kebijakankebijakan yang dibuat oleh negara. Berkaitan dengan kesempatan resmi oleh partai yang diberikan kepada perempuan, sebenarnya sudah diatur melalui Undang-undang Nomor 2 Tahun 2008 dan diubah lagi menjadi Undang-undang Nomor 2 Tahun 2011 tentang Partai Politik yang dalam beberapa pasalnya menyebutkan:

1. Pasal 2 ayat (2): "Pendirian dan pembentukan Partai Politik sebagaimana dimaksud pada ayat (1) menyertakan $30 \%$ (tiga puluh perseratus) keterwakilan perempuan."

2. Pasal 2 ayat (5): "Kepengurusan Partai Politik tingkat pusat sebagaimana dimaksud pada ayat (3) disusun dengan menyertakan paling rendah $30 \%$ (tiga puluh perseratus) keterwakilan perempuan."

3. Pasal 20: "Kepengurusan Partai Politik tingkat provinsi dan kabupaten/kota sebagaimana dimaksud dalam Pasal 19 ayat (2) dan ayat (3) disusun dengan memperhatikan keterwakilan perempuan paling rendah $30 \%$ (tiga puluh perseratus) yang diatur dalam AD dan ART Partai Politik masing-masing."

Tentang peluang resmi perempuan diperkuat dibenarkan oleh Ketua KPUD Kabupaten Bangka, Bapak M. Hasan. Berdasarkan wawancara pada 22 Januari 2020, dikatakan:

"Kesempatan perempuan ikut berpolitik berdasarkan Undang-Undang Nomor 7 tahun 2017 tentang Pemilu, dan PKPU Nomor 20 tahun 2018 tentang Pencalonan Anggota DPR, DPRD Provinsi, dan DPRD Kabupaten/Kota, aturan ini membuat parpol untuk mengikutsertakan perempuan minimal $30 \%$ pada posisi yang strategis, dan memberikan ruang kepada perempuan untuk berpolitik. Jika tidak ingin mendapatkan sanksi, maka parpol harus melakukannya dan ini terbukti efektif.” 
Diberikannya angka $30 \%$ pada beberapa pasal dalam undang-undang yang ada tersebut merupakan sebuah kebijakan yang dilakukan dalam upaya memberdayakan kaum perempuan di Indonesia agar memiliki kesempatan yang sama untuk berpartisipasi dalam dunia politik, khususnya masuk dalam struktur kepengurusan partai politik dan ikut andil mencalonkan diri sebagai anggota legislatif. Namun, dalam kenyataannya, posisi-posisi strategis belum diprioritaskan untuk diisi oleh perempuan, baik di kepengurusan partai politik maupun parlemen. Hal ini tentu mempengaruhi perempuan dalam pengambilan keputusan, yakni terjadi ketimpangan lantaran perempuan umumnya ditempatkan sekadar sebagai anggota biasa. Dengan demikian, tidak berlangsung ideal implementasi yang harusnya dijalankan oleh partai politik selaku wadah dalam rekrutmen, kaderisasi, dan pendidikan politik, sekaligus unsur yang terlibat dalam mensosialisasikan kepada masyarakat bahwa perempuan harus diberikan ruang dan tempat yang cukup. Payung hukum yang resmi, baik di partai politik maupun di parlemen, semestinya lebih diperkuat lagi komitmen penerapannya. Jadi, aturan yang ada memang menjadi landasan yang kukuh untuk membuka partisipasi atau keterlibatan perempuan, bukan hanya sebagai pemenuhan kuota tanpa makna.

\section{Sumber daya sosial}

Partisipasi ditentukan oleh kelas sosial dan perbedaan geografis. Dalam kenyataannya tidak semua orang memiliki peluang yang sama berkenaan dengan sumber daya sosial dan sumber daya ekonomi untuk terlibat dalam partisipasi politik. Berkaitan dengan perbedaan geografis, terdapat juga perbedaan dalam partisipasi seperti usia, jenis kelamin, suku, tempat tinggal, agama, dan lain-lain.

Berdasarkan wawancara dengan Ibu Acit Karvina, anggota DPRD periode 2014-2019 dari PDI-P, pada 22 Januari 2020, hambatan yang dialami itu berupa:

"Dari keluarga besar tidak semuanya mendukung karena kita perempuan. Para pemilih perempuan tidak milih perempuan, kualitas SDM perempuan masih terus harus berbenah agar sama kemampuannya dengan laki-laki dalam segi kualitas intelektual, mental, finansial yang masih belum sebanding dengan laki-laki dan daya pemikat untuk dipilihnya. Terhambat dari pengurus KPU; PPL pada saat kampanye dihalanghalangi padahal sudah memberikan surat yang sudah dilengkapi dan sudah mengikuti aturan, ternyata saat ditelusuri ternyata keluarganya juga ikut mencalonkan diri.”
Berdasarkan wawancara dengan Ibu Suharrina, anggota DPRD priode 2014-2019 dari PAN, pada 23 Januari 2020, disebutkan:

"Selain tergantung masing-masing SDM saat menerima pelatihan yang diberikan partai, kendala perempuan yaitu secara finansial jika ingin terjun ke ranah politik, maka untuk sekarang selain mental, pendidikan karakter tapi juga ditekankan kebutuhan finansial perempuan juga harus mumpuni. Sebab, kalau dari keluarga, kan itu khusus keluarga. Jadi, perempuan utamanya harus mandiri dalam pemasukannya. Dukungan keluarga besar juga mempengaruhi di mana kadang perempuan dari keluarga dan masyarakat (memandang perempuan) dirasa masih kurang mampu untuk duduk di parlemen.”

Sumber daya sosial dan sumber daya ekonomi merupakan faktor yang mempengaruhi keterlibatan perempuan untuk ikut serta ke ranah politik. Sumber daya sosial diperlukan karena masih kuatnya anggapan meragukan kaum perempuan tampil dalam kepemimpinan politik. Sumber daya ekonomi merupakan hal yang perlu dimiliki; belum cukup bila sekadar mengandalkan dukungan keluarga dan suami dalam pendanaan. Bila seorang perempuan calon legislatif belum mandiri dalam penghasilan, maka hal ini termasuk persoalan yang sangat penting. Memiliki modal dan dukungan penuh pendanaan secara mandiri merupakan bekal untuk bersaing dengan laki-laki yang memang sejak awal sudah eksis di dunia politik. Karena itu, faktor sosial dan ekonomi ini harus diatasi dengan adanya dukungan dari masyarakat dan keluarga untuk mempermudah akses perempuan bersaing di kancah politik.

\section{Motivasi diri}

Motif yang mendasari kegiatan berpolitik sangat beragam. Motif ini bisa sengaja atau tidak disengaja, rasional atau tidak rasional, diilhami psikologis atau sosial, diarahkan dari dalam diri sendiri atau dari luar, dan dipikirkan atau tidak dipikirkan. Hal ini merupakan faktor awal seseorang mencalonkan diri ke ranah politik, dengan motivasi diri merupakan fondasi utama, yakni kesungguhan memberikan jawaban atas pertanyaan: seberapa mau dan mampukah perempuan masuk ke ruang publik yang di sejak awal dianggap ruang laki-laki, dan perempuan tidak sekadar menjadi penumpang pelengkap?

Berikut ini hasil wawancara dengan para narasumber terkait motivasi mereka terjun ke panggung politik. 
Dalam wawancara dengan Ibu Suharrina, anggota DPRD periode 2014-2019 dari PAN, pada 23 Januari 2020, dijelaskan:

"Agar bisa ikut terlibat dalam pembuatan kebijakan bukan hanya jadi penonton saja, apalagi untuk kepentingan perempuan. Maka, penting sekali jika bukan perempuan yang di parlemen, siapa yang akan mengawasi eksekutif dalam menjalankan kebijakan yang berhubungan dengan perempuan, anak, rumah tanggal dan lainlain? Sedangkan permasalahan perempuan tentunya lebih dipahami oleh kaum perempuan sendiri. Bapak-bapak mana paham secara detail?”

Wawancara dengan Ibu Acit Karvina, anggota DPRD periode 2014-2019 dari PDI-P, pada 22 Januari 2020 menyebutkan:

"Ingin menyuarakan agar perempuan memilih perempuan, meningkatkan perlindungan anak tingkat daerah, provinsi dan pusat, meningkatkan kesejahteraan ibu-ibu. Intinya, ke depan perempuan percaya dengan perempuan. Jika banyak laki-laki di parlemen, mungkin mereka kurang menyerap permasalahan perempuan."

Kemudian wawancara dengan Surya Erni, anggota DPRD 2014-2019 dari Nasdem, pada 13 Januari 2020 mengungkapkan:

"Karena ingin belajar berpolitik dan berperan andil dalam kepentingan orang banyak.”

Wawancara dengan Ibu Deasy Arisandi, anggota DPRD periode 2014-2019 dari Gerindra, pada 13 Januari 2020 menerangkan:

"Ingin perempuannya lebih proaktif dan mandiri, kemudian untuk menyuarakan kepentingan perempuan agar kebijakan yang ada bisa dikawal dengan baik. Walaupun belum maksimal memang, tapi tetap ada controlling dan titik fokus dari perempuan ambil peran di parlemen, karena memang perempuan yang lebih paham permasalahan perempuan, dan agar bisa membantu lebih banyak orang dengan adanya ibu di parlemen.”

Bisa disimpulkan motivasi diri keempat anggota dewan di atas berpengaruh terhadap keberhasilan mereka dalam partisipasi ke ranah politik. Seyogianya memang semangat dan tujuan partisipasi yang ingin dicapai diseimbangkan dengan motivasi diri, dukungan keluarga, dan keterlibatan partai dan pemerintah. Semua ini faktor awal dalam upaya meningkatkan keterwakilan perempuan di parlemen. Saat caleg perempuan menghadapi tantangan, diskriminasi, ketidakpercayaan dari pemilih, semua hambatan ini tidak akan menjadikan mereka berputus asa dan menyerah dalam persaingan politik. Mental mereka sudah dipersiapkan dalam menghadapi pelbagai risiko ketika ikut serta dalam partisipasi politik yang memang penuh persaingan ketat dan sarat intrik.

\section{KESIMPULAN DAN SARAN}

\section{Kesimpulan}

Berdasarkan uraian pada pembahasan tentang keterwakilan perempuan pada DPRD Kabupaten Bangka Tahun 2014-2019, peneliti menarik kesimpulan:

1. Proses rekrutmen yang dilakukan partai politik di Kabupaten Bangka menggunakan model rekrutmen campuran yaitu terbuka dengan sistem stelsel aktif yang mempunyai pola immediate survival, dan model tertutup dengan sistem pasif yang mempunyai pola partisipan dan compartmentalization. Terdapat kekurangan dan kelebihan masing-masing model, sistem, dan pola yang diterapkan ini. Ke depannya hal ini harus dipertimbangkan oleh partai-partai politik dalam menjalankan komitmen untuk mengikutsertakan perempuan di dunia politik.

Bagaimanapun juga rekrutmen yang dilakukan akan mempengaruhi kuantitas, kualitas, dan keterwakilan perempuan di parlemen. Menurut Shvedova dalam Ranto (2019: 14), keterbatasan politisi perempuan dalam mengaktualisasikan aspirasi politiknya disebabkan oleh struktur politik dalam proses rekrutmen perempuan di arena politik. Ketika proses rekrutmen perempuan tidak dijalankan dengan maksimal, tingkat representasi perempuan lebih berfungsi sebagai untuk mempertahankan status quo daripada berfungsi bagi demokratisasi sebagaimana yang diinginkan. Ketika proses rekrutmen yang dilakukan tidak disertai prosedur-prosedur yang tertulis dan mengikat, kualitas perempuan yang dicalonkan pun seakanakan tidak sungguh-sungguh diunggulkan. $\mathrm{Hal}$ ini bisa dilihat dari tidak ditempatkannya perempuan pada posisi urutan strategis sehingga akhirnya politisi perempuan sulit mendapatkan tempat di ranah publik patriarkis yang masyarakatnya cenderung masih awam terkait keterwakilan perempuan di parlemen.

Sistem rekrutmen yang dilakukan partai politik di Kabupaten Bangka seharusnya memberikan dampak bagi peran perempuan sebagai wakil rakyat di parlemen. Sayangnya, menurut 
pengamatan peneliti, hal ini belum berjalan secara optimal. Para anggota dewan dari kalangan perempuan belum terlalu menyuarakan isu terkait perempuan. Penyebabnya adalah mereka hanya sibuk menjalankan tupoksi yang telah ditetapkan partai, dan tidak mendapatkan posisi yang strategis dalam jabatan pengambilan keputusan di partai. Sehebat apa pun kiprah politisi perempuan dalam mewarnai dinamika proses kebijakan publik, namun pada akhirnya masih menghadapi pemarginalan. Kondisi semacam ini tentu saja mampu menghambat tampilnya politisi perempuan yang berkualitas. Di sisi yang lain, untuk menyuarakan isu perempuan juga belum maksimal dilakukan kalangan perempuan legislator. Dari segi kuantitas, jumlah mereka sedikit (sebanyak 2 orang dari 7 anggota perempuan di parlemen merupakan PAW selama 1 tahun) sehingga kurang memiliki kekuatan mempengaruhi yang berarti di parlemen. Ketidakseimbangan ini membuat keterwakilan perempuan di parlemen semacam pelengkap saja karena berfungsi sama dengan pihak laki-laki yang menjalankan fungsi yang ada sesuai tupoksi. Oleh karena itu, tetap menjadi kendala merepresentasikan kepentingan perempuan dalam pembuatan suatu kebijakan; selain itu, masih sulit penanganan permasalahan ketimpangan gender yang ada dalam segala sektor. Ranah pembuat kebijakan yang ada belum responsif gender, yang ditandai dengan belum ditempatkannya perempuan pada posisi yang strategis dalam mengambil keputusan dan minimnya jumlah keterwakilan perempuan di parlemen. Semua ini pada akhirnya akan berpengaruh terhadap keluaran-keluaran kebijakan yang seharusnya mengatasi permasalahan yang ada berkenaan dengan perempuan.

2. Faktor keterwakilan perempuan dipengaruhi bagaimana peluang resmi yang diberikan partai politik dan pemerintah dalam struktur kepengurusan partai politik. Temuan yang didapat menjelaskan betapa peran perempuan memang belum diprioritaskan. Politisi perempuan belum maksimal untuk dipercaya dengan diberikan jabatan strategis di partai politik. Padahal, dengan tidak adanya keterwakilan perempuan dalam jabatan strategis di partai politik tentu saja semakin menutup peluang bagi tampilnya politisi perempuan berkualitas untuk berkiprah dalam dunia politik di parlemen. Belum maksimalnya dukungan sumber daya sosial (yaitu keluarga dan masyarkat) dan dukungan sumber daya ekonomi yang dimiliki dan yang diberikan kepada kaum perempuan jika ingin terjun ke ranah politik dan parlemen, turut mempengaruhi dalam proses pengikutsertaan perempuan di kancah politik. $\mathrm{Hal}$ ini berpengaruh memperlambat akses keterlibatan perempuan yang berminat di ranah politik. Di sisi yang lain, belum ada kesadaran yang dimiliki banyak perempuan untuk meningkatkan kualitas diri dengan mengambil bagian di partai politik dan parlemen. Padahal, hal ini merupakan faktor awal yang mempengaruhi upaya meningkatkan keterwakilan perempuan di parlemen.

\section{Saran}

Berdasarkan kesimpulan di atas, peneliti merekomendasikan beberapa saran berikut:

1. Perlunya kejelasan prosedur-prosedur yang mengikat dalam proses perekrutan calon bakal legislatif sehingga kesungguhan dari partai politik terhadap pemberian posisi strategis bagi perempuan untuk mencalonkan diri memang berdasarkan kemampuan dan potensi, bukan sebagai pelengkap sesuai ketentuan mencukupi kuota. Saat yang sama, diperlukan adanya: a) edukasi politik kepada kader dan bakal calon legislatif secara berkala; b) perekrutan bakal calon legislatif sebaiknya dilakukan jauh hari sebelum pemilu; c) sosialisasi kepada masyarakat terkhusus perempuan untuk mau menyuarakan keterwakilan perempuan di parlemen merupakan langkah sangat penting agar keterwakilan perempuan dapat ditingkatkan secara kuantitas dan kualitas.

2. Diperlukan payung hukum yang jelas dalam mewajibkan penempatan politisi perempuan pada posisi-posisi yang strategis di partai politik sehingga perempuan bisa menduduki jabatan pengambil keputusan di internal partai maupun di parlemen minimal 30\%. Dengan demikian, komposisi keadilan gender untuk mengakomodasi keterwakilan perempuan bukan sekadar dalam posisi sebagai anggota di parlemen, namun juga diprioritaskan sebagai unsur pimpinan parlemen. Diperlukan adanya payung hukum untuk pembatasan periode bagi para politisi yang sudah terlibat di parlemen agar bermunculan generasi kader baru di kancah parlemen, terutama untuk membuka kesempatan pada politikus perempuan berbakat.

3. Terkait poin saran ke-2, diperlukan adanya payung hukum secara resmi yang harus dijalankan partai 
politik dan pemerintah dalam struktur kepengurusan partai politik dan struktur di parlemen yang wajib melibatkan 30\% keterwakilan perempuan pada posisi strategis. Dengan demikian, perekrutan perempuan bukan hanya untuk mencukupi kuota tapi juga untuk kesadaran atas urgensi kebutuhan. Secara kultural diperlukan dukungan dari keluarga disebabkan dalam hal dukungan mental dan pendanaan untuk bergerak di ranah politik memang perempuan masih memiliki banyak kendala. Mengingat tak sedikit calon perempuan belum mandiri secara finansial, maka dukungan lebih kepada politisi perempuan dari partai politik sebagai komitmen peningkatan keterwakilan perempuan di parlemen sangatlah diperlukan. Demikian pula dalam hal dukungan keluarga; karena ruang keluarga yang tidak selalu mendukung sepenuhnya perempuan untuk terjun ke ranah politik, hal ini harus ditangani lebih prioritas oleh partai politik. Seturut itu, diperlukan adanya edukasi politik yang berkala kepada masyarakat sehingga persoalan belum maksimalnya dukungan masyarakat-terkhusus kalangan perempuan-mampu diatasi. Dalam hal ini diberikan pemahaman kepada masyarakat perempuan agar memunculkan dan meningkatkan kepercayaan terhadap calon perempuan di parlemen. Untuk itu, perlu adanya inisiatif dan motivasi diri dari perempuan untuk meningkatkan kualitas dirinya saat terjun ke ranah politik sehingga masyarakat yakin bahwa perempuan juga bisa berperan di parlemen dan masyarakat terkhusus perempuan merasa terwakili kebutuhannya dengan adanya perempuan di politik. Oleh karena itu, jauh-jauh hari sebelum pemilu diperlukan adanya edukasi politik yang diberikan kepada bakal calon legislatif. Dengan begitu, sebagai wakil yang diusung partai, mereka sudah memahami peranannya ketika berkiprah di parlemen. Partai politik bukan asal mengusung orang tanpa membarenginya dengan pemberian edukasi secara matang untuk meningkatkan kemampuan bakal calon agar lebih siap. Jadi, dari sini akan terbuktikan apakah partai politik bersungguhsungguh ataukah tidak ketika melibatkan partisipasi perempuan; karena suatu idealisme ataukah demi memenuhi kuota belaka.

\section{DAFTAR PUSTAKA}

\section{Buku, Jurnal, Artikel}

Badan Pusat Statistik. (2019). "Persentase Kursi Yang Diduduki Perempuan Di DPR Dan DPRD (Persen), 1999-2014”. Diakses dari https://www.bps.go.id/indicator/40/1337/1/persentase-kursi-yangdiduduki-perempuan-di-dpr-dan-dprd.html "Keterlibatan Perempuan di Parlemen (Persen), 2010-2018”. Diakses dari https://www.bps.go.id/indicator/40/464/1/keterlibatan-perempuan-di-parlemen.html

. "Persentase Penduduk menurut Provinsi dan Jenis Kelamin (Persen), 2016-2018". Diakses dari https://www.bps.go.id/indicator/40/894/1/persentase-penduduk-menurut-provinsi-danjenis-kelamin.html

. "Indeks Pemberdayaan Gender (IDG) 2017-2019”. Diakses dari

https://www.bps.go.id/indicator/40/468/1/indeks-pemberdayaan-gender-idg-.html

. “Distribusi Jabatan Manager Menurut Jenis Kelamin (Persen), 2017-2019”. Diakses dari https://www.bps.go.id/indicator/40/1334/1/distribusi-jabatan-manager-menurut-jeniskelamin.html

“Indeks Pembangunan Manusia (IPM) menurut Jenis Kelamin 2018-2019”. Diakses dari https://www.bps.go.id/indicator/40/462/1/indeks-pembangunan-manusia-ipm-menurut-jeniskelamin.html 
Mukarom, Zaenal. (2008) "Perempuan dan Politik: Studi Komunikasi Politik tentang Keterwakilan Perempuan di Legislatif”. Mediator, Volume 9, Nomor 2, hlm. 257-270. Diakses dari https://ejournal.unisba.ac.id/index.php/mediator/article/view/1125/681

Nugroho, Riant. (2008). Gender dan Administrasi Publik. Yogyakarta: Pustaka Pelajar

Prastowo, Andi. (2011). Metode Penelitian Kualitatif: dalam Perspektif Rancangan Penelitian. Jogyakarta: ARRuzz Media

Purwanto, Erwan Agus, dan Dyah Ratih Sulistyastuti. (2015). Implementasi Kebijakan Publik. Yogyakarta: Penerbit Gava Media

Putra, Fadillah. (2007). Partai Politik dan Kebijakan Publik. Yogyakarta: Pustaka Pelajar

Ranto (2019) “Mengakselerasi Politik Perempuan di Parlemen: Dari Hulu Hingga Hilirisasi”, Fisip UBB, hlm. 47

Rasyidin dan Fidhia Aruni. (2016). Gender dan Politik: Keterwakilan Wanita dalam Politik. Lhokseumawe: Universitas Malikussaleh Press (Unimal Press)

Romli, Lily. (2005). Pemilihan Presiden Langsung 2004 dan Konsolidasi Demokrasi di Indonesia. Jakarta: Pusat Penelitian Politik LIPI

Soetjipto, Ani Widyani. (2005). Politik Perempuan Bukan Gerbana. Jakarta: Penerbit Buku Kompas

Strauss, Anselm dan Juliet Corbin. (2009). Dasar-Dasar Penelitian Kualitatif. Yogyakarta: Pustaka Pelajar

Sustainable Development Goals (SDGs). “Tujuan 05”. Diakses dari https://www.sdg2030indonesia.org/ pada 10 Februari 2020

Undang-undang dan Peraturan

UUD Negara Republik Indonesia Tahun 1945

Undang-Undang Nomor 39 Tahun 1999 tentang Hak Asasi Manusia

Undang-Undang Nomor 2 Tahun 2011 tentang Partai Politik

Undang-Undang Nomor 8 Tahun 2012 tentang Pemilihan Umum Anggota DPR, DPD dan DPRD

Undang-Undang Nomor 7 Tahun 2017 tentang Pemilihan Umum

Instruksi Presiden RI Nomor 9 Tahun 2000 tentang Pengarustamaan Gender

Peraturan KPU Nomor 20 Tahun 2018 tentang Pencalonan Anggota DPR, DPRD Provinsi, dan DPRD

Kabupaten Kota 
